\title{
E-WASTE: AN UNDERRATED HAZARDOUS WASTE IN INDONESIA
}

\author{
I. T. Wilyani ${ }^{1}$, J. K. Nugraha ${ }^{2}$, M. A. Aryadi ${ }^{3}$, and N. Mariam ${ }^{4}$ \\ Faculty of Engineering, President University \\ J1. Ki HajarDewantara, Jababeka Education Park, Cikarang, Jawa Barat 17550 \\ 1indahtriawilyani@yahoo.com, ${ }^{2}$ jagatkn@yahoo.com, ${ }^{3}$ ariefaryadi383@gmail.com, ${ }^{4}$ nidacps007@ gmail.com
}

\begin{abstract}
The quick advancement of gadgets innovation industry offers an extensive variety of item decisions. This circumstance supported the improvement of electronic industry in Indonesia to be quick. The speeding up development is combined with items that are quickly out of date on the grounds that more current age items have showed up once more. So that, the electronic things which have been unused in the end move toward becoming refuse that is frequently alluded to as Electronic Waste (e-squander) and encountered an exceptionally fast increment. From the aftereffects of research in creating nations including Indonesia, E-Waste isn't found in squander Final Disposal (TPA). This is because of the high number of reusing and reuse (reusing) of utilized electronic products in the casual division. Reusing of the casual division is firmly identified with natural and wellbeing impacts. It isn't understood that numerous segments of electronic products contain hazardous toxic substances (B3). With a specific end goal to handling these issues, creating nations including Indonesia require modern cycle innovation, as well as significant administration measures and the presence of an approach to avert ecological effects. Nevertheless, contrasted and specialized viewpoints, e-squander administration strategy turns out to be more essential and earnest. In this paper, we endeavor to present the conditions and administration approaches that exist in Indonesia today and elective e-waste reusing innovations that identify with e-squander administration arrangements that are coordinated in the formal and casual segments.
\end{abstract}

Keywords: e-waste. informal sector, integrated management.

\begin{abstract}
Abstrak: Kemajuan cepat industri inovasi gadget menawarkan berbagai macam keputusan barang. Keadaan ini mendukung peningkatan industri elektronik di Indonesia menjadi cepat. Perkembangan yang semakin cepat digabungkan dengan item-item yang cepat ketinggalan zaman dengan alasan bahwa semakin banyak item usia sekarang muncul sekali lagi. Oleh karenanya, barang-barang elektronik yang tidakdigunakan pada akhirnya bergerak menuju menjadi sampah yang sering disinggung sebagai Sampah Elektronik (E-Waste) dan mengalami peningkatan yang sangat cepat. Dari efek samping penelitian dalam menciptakan negara termasuk Indonesia, E- waste tidak ditemukan di Pembuangan Akhir (TPA) penghamburan. Hal ini karena tingginya jumlah untuk menggunaan kembali dan penggunaan kembali (reusing) produk elektronik yang digunakan di divisi kasual. Menggunakan kembali dari divisi kasual secara tegas diidentifikasi dengan dampak alami dan baik. Tidak dipahami bahwa banyak segmen produk elektronik mengandung Bahan Berbahaya dan Beracun (B3). Dengan tujuan akhir yang spesifik untuk menangani masalah ini, menciptakan negara termasuk Indonesia memerlukan inovasi siklus modern, serta langkah-langkah administrasi yang signifikan dan adanya pendekatan untuk mencegah efek ekologi. Meskipun demikian, sudut pandang yang dikontraskan dan khusus, strategi administrasi e-waste ternyata lebih penting dan sungguh-sungguh. Dalam tulisan ini, kami berusaha untuk menyajikan kondisi dan pendekatan administrasi yang ada di Indonesia saat ini dan e-waste menggunakan inovasi yang mengidentifikasi dengan pengaturan administrasi e-penghamburan yang terkoordinasi dalam segmen formal dan kasual.
\end{abstract}

Kata Kunci: E-waste, Sektor Informal, Pengelolaan Terpadu.

\section{INTRODUCTION}

The quick improvement of the electronics technology industry not just offers an extensive variety of item decisions yet in addition value choices. This provides an opportunity for the community to have electronic items in their homes. This circumstance supports the improvement of the electronic business in Indonesia to be quick. The speeding up of development is combine with the items that are rapidly out of date as more up to date age items have returned. According to Osibanjo et al, (2006), in fact, electronic goods are usually not used anymore, even though they can still operate for later replaced with new ones because consumers want new features or old ones inadequate for new services from operators, or just because want to change it. With the goal that these unused electronic things in the end progress toward becoming junk which 
is frequently alluded to as Electronic Waste (e-waste) and encountered an extremely quick increment. In (Sutarto E, 2008), e-waste has different characteristics with other wastes. This is because the definition of e-waste is very dependent from the perspective of each person.

In their research Jesica et al (2011), in Indonesia in 2007 produced more than 3 billion units of household electronic equipment and IT equipment. Still in Jesica's research it is stated that Indonesia is one of the biggest consumers of household electronic equipment in Asia. From these data can be imagined in the coming year in Indonesia will experience e-waste boom. While developing countries including in Indonesia there is no agreement on standard or generally accepted definitions. Whereas according to the results of Fishbein (2002); Scharnhorst et al (2005) cited by Jang et al (2010), toxic substances in arson, beryllium, cadmium and tin are found to be very presistent and as substance. bioaccumulation. If during the repairing and recycling process of e-waste is uncontrolled, some of these chemicals can be released into the environment. Because the shape is relatively small so that the impact of disposal is ignored. But with very fast growth, the impact is very significant on health and the environment.

Formally, because e-waste is included hazardous waste, Indonesia has forbidden to importe-waste but in fact can enter illegally (Sukandar, 2011). Meanwhile, according to Triwiswasra (2009) in creating nations including in Indonesia, there are exercises of repair and reuse of utilized electronic products in high amounts. Repair shops can be found in the secondhand sector. The workers at the storelook for broken or unused components and replace them with new locally made components. Components damaged already severe and can not be reused, still have a sale value because it can still be recycled.
According to Widyarsana (2011), e-waste recycling in Indonesia takes place uniquely, where the focus of attention is on the components of Electronic Product is so high that the life time component is getting longer or end-of-life becomes long. Uncontrolled utilization by the informal sector can have health and environmental impacts. In order to address the problem, it currently requires not only sophisticated cycle technology, but also management measures that are relevant to environmental prevention policies. Compared with technical aspects, the ewaste management policy becomes more important and urgent for this specific situation, so it does not just apply the management that has been done in other countries. This paper endeavors to present current e-squander administration arrangements and conditions and additionally elective e-squander reusing innovations identified with coordinated and casual e-squander administration strategies.

\section{E-WASTE CONDITION IN INDONESIA}

Although e-waste appears as a global issue, it is not a common term for most people in Indonesia. There is no particular meaning of e-waste in existing controls in Indonesia, although in developed countries (EU Directive), it is clear that e-waste includes hazardous waste regulations. Where in the regulation e-waste can be interpreted as electronic goods and electrical equipment that is not used and or has been unwanted because it has become obsolete items and need to be discarded, either in the form of whole or as part. Compared to other developing countries in Southeast Asia, awareness of e-waste problems in Indonesia is still relatively lagging behind. This is due to the lack of information regarding e-waste to the public and different understanding between institutions regarding waste and procedures management at the government level. In addition, there is no accurate data 
for the number of electronic goods in Indonesia and no other technical provisions on the age of reprocessed goods. If e-waste is considered a hazardous waste, it should end up in a landfill as well so it is safe for hazardous waste. Research conducted by Damanhuri and Sukandar (2006), e-waste is not found in Final Disposal (TPA) waste. e-waste sold is usually only part of an electronic component or only one piece or component parts are usually sent to the assembly plant again. This indicates that there is an unofficial system that absorbs most of e-waste in Indonesia, namely the finding of flow of secondhand electronic materials and electronic waste (e-waste).

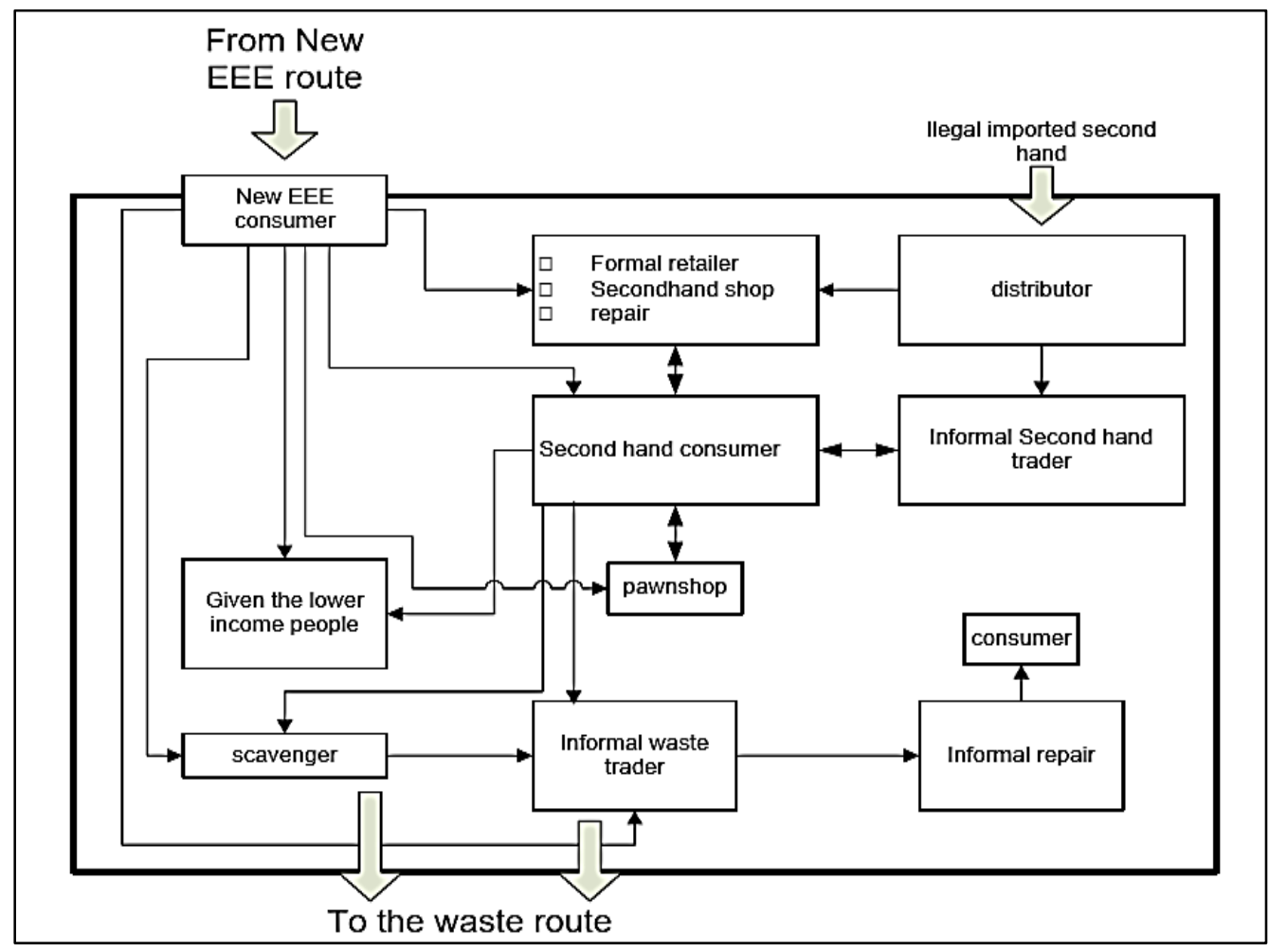

Figure 1.Flow of Electronic Goods and Equipment (EEE) Secondhand Source: Damanhuri and Sukandar, (2006)

Electronic waste generation forecasts in Indonesia have been issued by the STEPInitiative organization and show that in 2012, electrical and electronic devices circulating for sale in the Indonesian market amounted to 1.361 kilotonnes or 1.361 million $\mathrm{kg}$. Two years later, electrical and electronic devices are estimated to be still used or circulated in the community, both in the condition still functioning as early as the purchase and have been repaired only amounted to 616 million $\mathrm{kg}$. So that devices which have become electronic waste in 2014 is predicted to amount to 745 metric kilotonnes or about 745 million $\mathrm{kg}$, and Thereis no particular meaning of e-waste in existing controls in Indonesia. To regulate electronic waste, the government has been categorizing electronic waste into hazardous and toxic waste. Therefore, the regulation and management of electronic waste refers to regulations regulating hazardous waste and waste, namely Law no. 32 of 2009 concerning environmental protection and management; Presidental Decree no. 101 of 2014 concerning hazardous waste management; and Law No. 18 of 2008 on waste management. However, all of these regulations only 
govern general and do not specify the waste management. definition, criteria or flow of electronic

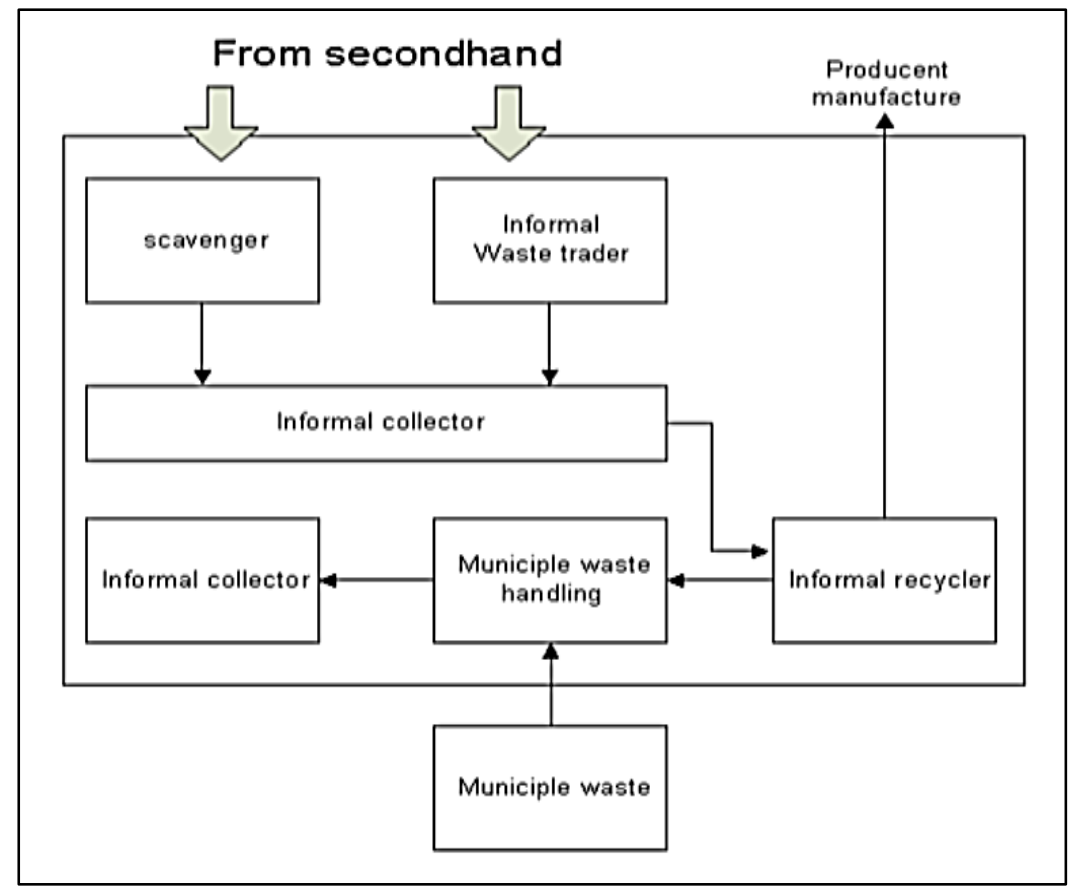

Figure 2. Flow of E-Waste

Source: Damanhuri and Sukandar, (2006)

This weak of legal framework ultimately impacts on the frequent occurrence of violations which in addition to harming the state also pollute the environment and threaten public health, because it is not done through the way environmentally friendly. Such as the sending of electronic waste from abroad into the territory of the Republic of Indonesia which still occurs even though the prohibition of importation of electronic waste has been regulated in Law No.32 of 2009 article 69 paragraph 1 and Law No.18 of 2008 Article 39 paragraph 2. As an archipelago, Indonesia has many ports scattered in the outer islands so that electronic waste or used electronic devices from abroad enter the national market through these ports by utilizing the limitations of officers and standard service facilities of supervision on the importation of goods that are prohibited from entering the country, as well as forgery or the use of inappropriate permissions documents. This then allegedly contributed significantly to the amount of electronic waste in Indonesia, even though the data regarding the illegal import of electronic waste, these cannot be monitored by the government.

While the impact of pollution due to the management of electronic waste that is not environmentally friendly has occurred in several regions in Indonesia. Like the case of environmental pollution that occurred in Pesarean Village, Adiwerna District, Tegal Regency. This village has several metal industries that smelter aluminum, lead, copper, zinc and used batteries. The results of the remaining metal industry activities have caused a pile of metal wastes such as lead ingots produced and become raw materials for industrial batteries, electronics, metal plating, paint, glass and others. In 2011, the results of a regional sample test conducted by the Central Java Provincial Government on 50 villagers provided data that as many as 46 people had been 
contaminated with lead and of these, 12 people were in danger because of exposure to a number of harmful substances.

\section{VULNERABLE POPULATIONS}

Minimized population bear an unbalanced measure of the negative impacts of despicable e-squander rehearses. Most ewaste recyclers, in either the formal or casual segment, are poor and less instructed than the particular populace normal, Diaz-Barriga (2013). E-waste reusing gives a wellspring of wage to individuals who have couple of other monetary openings. E-waste reusing, particularly in the casual area, is designed for high throughput and yield. Word related security and natural insurance are not organized. Poor kids and ladies, particularly those living in urban territories, speak to an expansive segment of e-waste recyclers, Chi X et al (2011). Because of the holes in information, especially in the casual segment, the aggregate number of kids presented to word related wellbeing and dangers from e-waste is hard to evaluate. Notwithstanding, the International Labor Organization has detailed that e-squander specialists are regularly kids, Lundgren $\mathrm{K}$ (2012). Kids are viewed as perfect e-waste laborers since they have little, adroit hands that assistance them effortlessly disassemble disposed of EEE.

The abuse of kids inside the e-waste reusing industry is particularly concerning given the physiological credits that add to a tyke's helplessness. Exposures to unsafe substances, for example, polychlorinated biphenyls and dioxins, at e-squander destinations are higher for kids than for grown-ups. Youngsters are as yet developing so their admission of water, nourishment, and air in extent to their tallness and weight is altogether higher contrasted with the admission of grownups (Duffert C). Children likewise have a significantly bigger proportion of surface zone to body weight than grown-ups, bringing about a lifted hazard for dermal retention (Duffert C). Moreover, youngsters have a diminished capacity to detoxify substances. Amid development, a kid's creating frameworks are fundamentally more touchy to harm. Kids regularly invest more energy outside where perilous exposures are inside nearer closeness. From a conduct stance, young children commonly show hand-to-mouth conduct and creep on the ground, which typically prompts the immediate ingestion of possibly unsafe substances. Kids have an immature hazard discernment that can prompt destructive exposures from ewaste, Caravanos J et al (2013). At last, children have a more extended future amid which they would live with the impediment that wounds or introduction to dangerous substances can incite.

\section{EFFECTS OF EXPOSURE}

The short-and long term impacts of introduction to risky e-waste substances are not completely seen, be that as it may, there is inquire about on the relationship between e-waste presentation and more elevated amounts of synthetic compounds and metals in human-inferred natural examples, (Duffert C). The lethality of numerous individual substances found in e-squander is all around archived, nonetheless, the harmfulness of the blends of substances prone to be experienced through e-waste reusing is less notable. Overwhelming metals and halogenated mixes seem to impact potential wellbeing dangers, (Duffert C).

The potential antagonistic wellbeing impacts of introduction to ewaste have been explored as of late and may incorporate changes in lung work, thyroid capacity, hormone articulation, birth weight, birth results, youth development rates, psychological wellness, intellectual improvement, cytotoxicity, and genotoxity, (Duffert C). It is likewise conceivable that presentation to dangerous synthetic compounds delivered by e-waste reusing may have cancer-causing impacts and endocrine upsetting properties that 
could prompt deep rooted changes because of neuro development inconsistencies, anomalous conceptive advancement, scholarly hindrance, and consideration troubles, (WHO). Raised levels of 8hydroxydeoxyguanosine, a urinary biomarker of summed up, cell oxidative pressure, were seen in the post-work-move pee of e-waste laborers. One investigation of Chinese e-waste specialists recorded essentially larger amounts of serum polybrominateddiphenyl ethers (PBDEs) and thyroid-empowering hormone (TSH) than found in the control gathering, Wen $\mathrm{S}$ et al (2008). The expanded presentation to PBDEs from ewaste reusing may prompt obstruction with the thyroid hormone framework and other unfavorable wellbeing impacts, Wen S et al (2008). Decreased lung function has been seen in young men matured 8 to 9 years living in an e-squander reusing town however not in young men living in a control town, Grant $\mathrm{K}$ et al (2013). Huge negative connections between's constrained essential limit, a measure of lung capacity, and blood chromium fixations have been accounted for. Grant K et al (2013). Lead is additionally a built up neurotoxicant that can prompt scholarly impedance and harm to the anxious, blood, and conceptive frameworks. Research discoveries show there is no limit beneath which lead presentation does not effects lyaffect a creating sensory system,(Duffert C). Brominated fire retardants have a long half-life and supposedly prompt debilitated learning and memory work; changed thyroid, estrogen, and hormone frameworks; social issues; and neurotoxicity. Cadmium tends to bioaccumulate and can be profoundly lethal, particularly to kidneys and bones. Mercury is thought to make harm the mind and focal sensory system, especially amid early advancement. The quantity of unsafe substances that people could be specifically or in a roundabout way presented to by e-squander is huge and hard to measure. The groupings of these materials are variable yet frequently are quite high, particularly inside the genuine e-waste locales. Regardless of whether the centralizations of these substances are low, the synthetic concoctions are frequently still lethal to people and diligent in nature. The heterogeneous idea of risky exposures adds to the challenges encompassing the investigation of the impacts e-squander exposures.

There are extra parts of e-waste presentation that may prompt unfavorable wellbeing results. Regardless of whether every day introduction is low, aggregate presentation is frequently high and to a great degree difficult to gauge, (Duffert C). Notwithstanding, when the impacts of a solitary concoction at specific levels are very much concentrated the impacts of the blends of unsafe e-waste substances are not notable. Inside a blend of synthetic concoctions, a few substances may have synergistic or adjusting impacts that could be to a great degree unsafe, (Duffert C). The reagents utilized as a part of the reusing procedure, such cyanide and other solid draining acids, may add to the dangerous synthetic e-waste blends. Not exclusively do the day by day and total measurements of introduction matter while ascertaining hazard, yet in addition the planning, or "life phase of presentation" is profoundly noteworthy, van den Berg (2013). Unmistakably, destroying e-waste can likewise specifically prompt damage. Certain people, for example, kids, are more helpless given the affectability of their creating frameworks. The planning of presentation likewise may demonstrate the normal span of certain subsequent wellbeing impacts of introduction.

Much research is required on esquander introduction and potential unfriendly wellbeing impacts. Solid confirmation that connections occupation introduction of perilous e-squander substances to wellbeing impacts is deficient. The potential causal connection amongst presentation and watched negative impacts requires extra, broad 
research. Additionally, the blend of ewaste auxiliary synthetic substances and organic specialists is obscure. For instance, the communication amongst lead and mercury with the intestinal sickness parasite requires facilitate examination. On an exceptionally fundamental, human level, innovative work of treatment measures for those presented to perilous ewaste materials is basic. Research on ewaste perils can be restricted by poor access to uncontrolled settings, constrained assets, and political and moral concerns. Observing and reconnaissance, particularly of casual e-waste reusing activities, is meager. In spite of these examination hindrances, additionally considers are indispensable. Not exclusively are hazard appraisals of e-waste presentation basic, yet in addition investigate that will encourage casual neighborhood, provincial, and worldwide e-waste reusing arrangement is required earnestly.

\section{E-WASTE MANAGEMENT POLICY IN INDONESIA}

The legal basis for electronic waste management (e-waste) includes:

- Presidential Decree 61/1993 on the Ratification of the Basel Convention.

- Presidential Regulation 47/2005 on Ratification of Ban Amandement

- Law No. 32 of 2009 on Environmental Management

- Presidental Decree No. 18/1999 no Presidental DecreeNumber 85/1999 on B3 Waste Management

- Law No. 18 of 2008 on Waste Management

In Government Regulation No. 18/1999 no Presidental Decree No. 85/1999 on Hazardous Waste Management mentioned in detail as follows:

a) Hazardous waste from a specific source (Annex I, Table 2 "List of B3 Wastes from Specific Source" Waste Code D219: Electronic Components / Electronic Equipment) b) Source of Pollution: Manufacturing and Assembling; Waste Water Management

c) Origin / Waste Description: sludge remaining process; coated glass (CRT tube); solvent used; painting waste; solder residues and fluxes (PCB, IC, cable); plastic casing

d) Other waste outside the category of B3 waste can be organic or inorganic

Although in recent years, foreign countries, especially the European Union, have issued a series of appeals (such as RoHS, WEEE instructions and others) to promote the eco-design of electrical products and adopt Extended Producer Responsibility (EPR) for the collection and recycling of WEEE, but at the reality is still very difficult to apply directly in developing countries. In Indonesia, the draft Regulation of the Minister of State on Electronic Waste Management will be arranged in terms of definition, scope of electronic waste source, electronic waste type, Extended Producer Responsibility (EPR), electronic waste management through hazardous waste management mechanism, cooperation between producers of electronic goods and hazardous waste managers and their compensation and supervision.

\section{MANAGEMENT OF E-WASTE INTEGRATED FORMAL AND INFORMAL SECTOR IN INDONESIA} The recycling of electronic goods by the informal sector is not new and is the development of recycling practices of low cost e-waste in the management of e-waste this is the case in several developing countries as well as Republic of Indonesia, wherever there's a niche in environmental management, the high demand for secondhand or secondhand electronic equipment and e-waste sales for the collectors encourages strong recycling of the informal sector. The informal sector recycling is not only related to environmental and health impacts, but also 
the lack of recycling services in the formal sector. In Xinwen et al, (2010), experience has shown that merely prohibition or competitory with informal sector recyclers and formal recyclers isn't a good answer. The new formal employment system should take under consideration the informal sector, and therefore the policy improve employment, working conditions and the efficiency of the role of the informal sector.

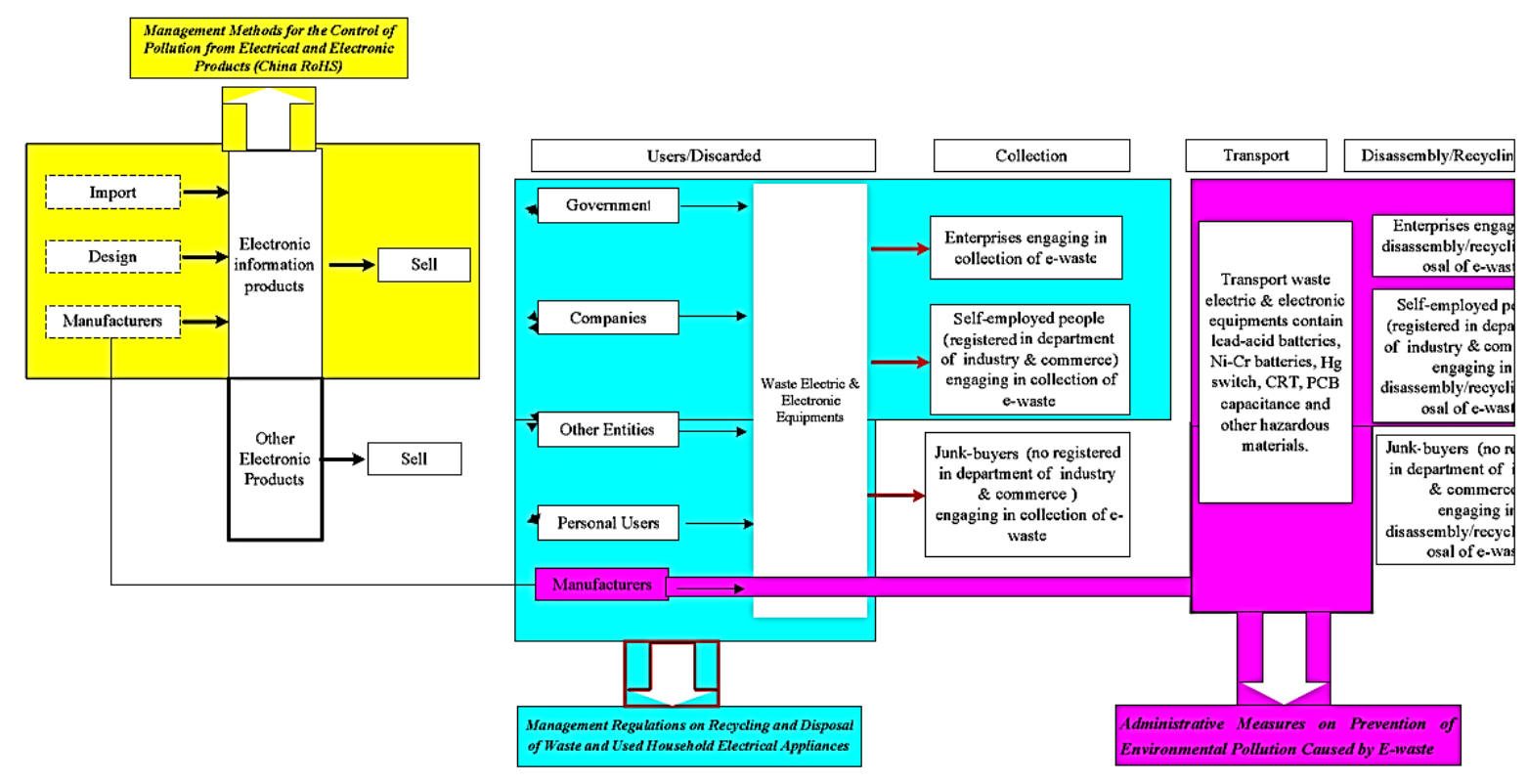

Figure 3. Management of Integrated Waste Source: Wen Xuefeng et al, (2009)

The main problem in managing e-wastein developing countries is the way to regulate incentives for use the informal sector thus on scale back undesirable cycle activity and to divert additional e-waste to flow into formal sector use. Still in Xinwen et al, (2010), it is reported that the formal and informal sector integrated e-waste management methods introduced in China and developing countries in general have been implemented on March 1, 2007 and their main ideas include:

1) During the design and production process, measurement techniques, such as research changes and design proposals, adjusting technology processes, replacing materials and using innovative methods in the production process, and others.

2) During the process of design, production, import and sale, steps such as identification of the names of toxic substances and hazardous substances and their elements and levels and terms for the environment used by electronic products, and others.

3) During the sales process, there must be strict supervision from the buyer's channel, withholding the sale of electronic goods containing B3, finding industry standards for pollution control by electronic products.

4) Prohibition for the import of electronic goods failing to meet the standards for B3 supervision.

\section{CONCLUSION}

Indonesia which is one of the countries in Asia that has sizable amount of electronic home aplliances consumption, and became one amongst the foremost manufacturing e-waste country in Asia. there are several of Indonesian individuals don't seem to be concern to e-waste since most of the 
individuals used associate instrumentality equipment for such an extended time even till the equipment visited the second-hand, it is aforesaid that the instrumentality is associate e-waste already. When the ewaste is employed for the while consumption it will caused a long exposure of the venturesome substances from noxious element of e-waste. E-waste utilization is critical however it ought to be conducted in a very safe and standardized manor. Once potential, e-waste ought to be refurbished and reused as an entire product rather than destroyed. Once restoration in unacceptable, e-waste ought to be destroyed by trained, protected, and wellcompensated staff in technologically advanced e-waste utilization facilities in each developed and developing countries.

There area unit many basic principles from that all e-waste regulation ought to be supported. First, acceptable risk thresholds for venturesome, secondary e-waste substances shoul not diverge for developing and developed countries. However, the suitable thresholds ought to diverge for kids and adults given the physical variations and pronounced vulnerabilities of youngsters. Utterly eliminating the presence of toxicant elements in EEE, though economical, isn't realistic. though there area unit analysis desires, academic and awareness programs on the potential risks of e-waste use additionally ought to be developed and enforced. These programs area unit of important importance in developing countries.up activity conditions for all ewaste staff and effort for the obliteration of kid labor is non-negotiable. Interventions ought to be specific to the native culture, the earth science, and therefore the limitations of the notably vulnerable communities. Policies that may offer incentives to market safe, regulated, and recompensed use for e-waste ought to be universal.

\section{ACKNOWLEDGEMENT}

The authors acknowledge Temmy Wikaningrum (President University) as the lecturer who gave the most motivation thus this paper can be done.

\section{REFERENCE}

Agustina, H., Identification of $E$ Waste and Secondhand E-Product in Indonesia, Presentation on Basel Convention Regional Meeting, Beijing:28-29 March 2007.

Chi X, Streicher-Porte M, Wang M.Y.L, Reuter M.A, (2011) Informal electronic waste recycling: a sector review with special focus on China.

Damanhuri, E. dan Sukandar,. Preliminary Identification of E-waste Flowin Indonesia And its Hazard Characteristic, Proceedings of Third NIES Workshop on E Waste, Japan:2006

Diaz-Barriga, F., (2013)Evidence-based intervention programs to reduce children's exposure to chemicals in e-waste sites. Discussion paper for WHO Working Meeting on $e$-waste and children's health.

Duffert C, Brune M. N, Prout K., Background document on exposures to e-waste. Geneva, Switzerland: World Health Organization.

Caravanos J, Clarke EE, Osei CS, Amoyaw-Osei Y, (2013)Exploratory health assessment of chemical exposures at e-waste recycling and scrapyard facility in Ghana. J Health Pollution.

Fishbein, B.K., Waste in the Wireless World: The Challenge of Cell Phones. INFORM, USA 2002.

Grant K, Goldizen FC, Sly PD, et al. (2013)Health consequences of exposure to e-waste: a systematic review.

Hanafi J, Helena K., (2011)The Prospect of Managing WEEE in Indonesia,. Proceeding of the 18th CIRP International Conference on Life Cycle Engineering, Germany

Jinglei Yu, Eric Williams, Meitiung Ju, Chaofeng Shao, Managing e waste in China: Policies, pilot projects and alternative approaches, Environment Science and Technology, 2010.

Liu XB, Tanaka M., Matsui Y., Generation amount prediction and material flow analysis of electronic waste: a case study in Beijing, China, Waste Manag Res 2006;24:434-45.

Lundgren, K., (2012) International Labor Office (ILO). The global impact of ewaste: addressing the challenge.

Osibanjo, Oladele dan Nnorom, Innocent Chidi. 2006.,Material Flows of Mobile Phones and Accessories in Nigeria: Environmental 
Implications and Sound End-of-Life Management Options. Environmental Impact Assessment Review vol. 28, p. 198-213.

Sukandar dan Widyarsana IMW.,(2009): Recycling of $E$ waste in Indonesia by Informal Sector: Case Study og Gold Recovery from $E$ waste Component, Proceeding The Sixth NIES Workshop on E waste, HokkaidoJapan,pp.151160

Sutarto, E., (2008), Identifikasi Pola Aliran Ewaste Komputer Dan Komponennya Di Bandung, ITB Bandung

UNEP., Basel Convention on the Control of Transboundary Movements of HazardousWastes and their Disposal, United Nations Environment Programme. http://www.basel.int/, 2009

Van den Berg, M., (2013) State of the art on risks of e-waste and children's health. Discussion paper for WHO Working Meeting on e-waste and children's health.

Wen, X., Xiaohua, Z.,(2009), The New Process in Integreted $E$ waste Management in China, University of Newcastle

Wen S, Yang FX, Gong Y, et al. (2008), Elevated leves of urinary 8-hydroxy-2'-deoxyguanosine in male electrical and elctronic equipment dismantling workers exposed to high concentrations of polychlorinated dibenzo-pdioxins and dibenzofurans, polybrominateddiphenyl ethers, and polychlorinated biphenyls.

WHO, The Geneva declaration on e-waste and children's health. Available at: http://cerch.org/ wp-content/uploads/Geneva-Declarationfinal.pdf.

Widyarsana IMW., Winarsih,D.R., Damanhuri, E., Padmi,T.,(2010) Identifikasi Material E-waste Komputer dan Komponen Daur Ulangnya di Lokasi Pengepulan E-waste,Bandung,2010. 